1 Associations between sustainable development goals accelerators and 2 well-being, by household heads' disability status among adolescents in 3 Zambia - a cross-sectional study.

${ }^{1 *}$ Institute of Global Health, University of Geneva, Geneva, Switzerland.

2 Joint United Nations Programme on HIV/AIDS (UNAIDS)

${ }^{3}$ Institute for Medical Information Processing, Biometry, and Epidemiology Medical Faculty, Ludwig Maximilians University München, Germany ${ }^{4}$ Centre for Social Science Research, University of Cape Town, Cape Town, South Africa. ${ }^{5}$ Department of Social Policy and Intervention, University of Oxford, Oxford, UK. ${ }^{6}$ Department of Sociology, University of Cape Town, Cape Town, South Africa.

${ }^{7}$ Social Work and Sociology, University of Zambia, Lusaka, Zambia.

${ }^{8}$ Disability Inclusion Project Luapula, International Labour Organisation, Lusaka, Zambia.

${ }_{9}^{9}$ Palm Associates Limited, Lusaka, Zambia.

${ }^{10}$ Economics and Agricultural Sciences, University of Zambia, Lusaka, Zambia.

${ }^{11}$ Centre for Evidence-Based Intervention, Department of Social Policy and Intervention, University of Oxford, Oxford, UK

${ }^{12}$ Department of Psychiatry and Mental Health, University of Cape Town, Cape

Town, South Africa

"Corresponding author: Email: chipanta@hotmail.com; david.chipanta@etu.unige.ch

E-mail addresses of authors:

JE: janne.estill@unige.ch

HS: heidi.stoeckl@ibe.med.uni-muenchen.de

LH: lucas.hertzog@uct.ac.za

ET: Elona.toska@uct.ac.za

PC: patrick.chanda@unza.zm ; patrickchanda@ymail.com

JM: jasonmwanza2@gmail.com

KK: kaira@ilo.org

CM: chisanqu@palmassociates.org

GT: tembogel@gmail.com

OK: Olivia.Keiser@unige.ch

LC: lucie.cluver@spi.ox.ac.uk 


\title{
Associations between sustainable development goals accelerators and well-being, by household heads' disability status among adolescents in Zambia - a cross-sectional study.
}

\begin{abstract}

\section{Objectives:}

We examined associations between accelerators (interventions impacting two or more SDG targets) and well-being indicators among adolescents in Zambia.

\section{Methods:}

We randomly sampled 1,800 households receiving social cash transfers (SCT) in four districts, surveyed adults 16 years and older. Using multivariable logistic regressions, stratified by household heads disability status, we examined associations between accelerators (SCT, life-long learning (LLL), mobile phone access (MPA)) and seven well-being indicators among adolescents 16 to 24 years old. We predicted adolescents' probabilities of reporting indicators using marginal effects models.
\end{abstract}

\section{Results:}

We included 1,725 adolescents, 881(51.1\%) girls. MPA was associated with no poverty (adjusted Odds Ratio [aOR] 2.08, p<0.001), informal cash transfers (aOR $1.82 \mathrm{p}=0.004)$, seeking mental support ( $\mathrm{aOR} 1.61, \mathrm{p}=0.020)$; SCT with no health access restrictions related to disability (aOR 2.56, $p=0.004$ ), lesser odds seeking mental support (aOR 0.53, $\mathrm{p}=0.029$ ); LLL with informal cash transfers (aOR 3.49, $p<0.001$ ), lower school enrolment (aOR 0.70, $p=0.004$ ). Adolescents living with disabled household heads reported worse poverty, good health, less suicidal ideation.

\section{Conclusions:}

Accelerators - SCT, LLL, MPA - were associated with well-being indicators.

Adolescents living with disabled household heads benefited less.

\section{Relevance to SDGs:}

This paper shows that adopting accelerators can help achieve SDGs-aligned wellbeing indicators for adolescents living in poverty. However, accelerators may not offset disability-related inequalities. Adolescents living with disabled household heads may require more attention to achieve the SDGs.

\section{SDGs targets:}

1.2. no poverty; 1.3 .1 social cash transfers, Informal cash transfers; 3 . good Health; 3.4. no suicidal ideation; 3.4. seeking mental support; 4.1. school enrolment; 10 . no health access restrictions related to disability. 
medRxiv preprint doi: https://doi.org/10.1101/2021.10.22.21264347; this version posted October 26, 2021. The copyright holder for this preprint (which was not certified by peer review) is the author/funder, who has granted medRxiv a license to display the preprint in perpetuity.

It is made available under a CC-BY-NC 4.0 International license .

\section{Introduction}

Adolescents are a crucial population group to attain the Sustainable Development Goals (SDGs). Individuals aged 15 to 24 years comprise 15.5\% (1.21 billion) of the global population, reaching 1.29 billion by 2030 [1]. Adolescence is a decisive period to intervene on multiple SDGs. The rapidly developing physical and mental growth, transition into adulthood taking place during adolescence have strong impact on health and well-being in adulthood [2,3]. In sub-Saharan Africa, where the growth of adolescents' population is fast, the potential to improve their well-being is more constrained [1]. The region's adolescents have high rates of mental health conditions, suicide, HIV, and other diseases [4]. A 10-year-old child is six times more likely to die by age 24 in sub-Saharan Africa than in North America or Europe. Globally, suicide is the second leading cause of death among adolescents aged 15 25 years [4]. Suicidal ideation, defined as a preoccupation with thoughts of killing oneself, and planning of suicide among adolescents aged 13-17 years in lowincome and middle-income countries were the highest in Africa [5]. Not being in employment, education, or training (NEET) also negatively impacts adolescents' well-being and successful transition into adulthood [6]. A quarter (25.9\%) of adolescent girls and $15.8 \%$ of boys in sub-Saharan Africa were NEET in 2019 [7]. Of those employed, the majority $(94.9 \%)$ were in informal employment, living in extreme poverty, on less than US $\$ 1.90$ a day [7]. Mobile phone use which is among interventions that could improve adolescents' achievements of the SDGs is also limited in the region $[8,9]$.

Urgent government coordinated actions are needed to accelerate the achievement of SDGs for the regions' adolescents, particularly in the context of the Coronavirus Disease 2019 (COVID-19) pandemic [10]. The United Nations Development Programme (UNDP) defines accelerators as interventions or circumstances that positively impacts two or more SDGs targets [11]. Studies on accelerators have shown multiple, large, and favourable changes in adolescents' mental health, the experience of transactional sex, violence, HIV prevention and treatment, and other SDG aligned outcomes from combining and re-arranging existing interventions. For example, social protection including cash transfers, education, safe schools, food security, parenting programmes, role of caregivers, and psychosocial support have been shown to be accelerators [12-14].

Disability is a serious threat to achieving the SDGs [15]. More than 1 billion people worldwide are estimated to be living with disabilities. The majority are left behind in several SDGs $[15,16]$. On the other hand, cash transfer programmes, in general not only include people with disabilities [15], but also often pair the programmes with training (life-long learning) to emphasize or explain programme objectives. The programmes also deliver cash and other services via mobile phones to individuals and households [17]. Social cash transfers (SCT), life-long learning (LLL) and mobile phone access (MPA) could potentially be accelerators and support adolescents in households headed by persons with disabilities. We, therefore, aimed to test whether SCT, LLL and MPA fulfil the definition of accelerator in this study, and how they interact with the household heads' disability status in improving the SDGs aligned well-being indicators for adolescents. 
medRxiv preprint doi: https://doi.org/10.1101/2021.10.22.21264347; this version posted October 26, 2021. The copyright holder for this preprint (which was not certified by peer review) is the author/funder, who has granted medRxiv a license to display the preprint in perpetuity.

It is made available under a CC-BY-NC 4.0 International license.

\section{Methods:}

\section{Data sources and sample}

125 We used the baseline data collected in August to September 2019 for the evaluation

126 of the United Nations Partnership on the Rights of People with Disabilities

127 (UNPRPD) project in Luapula province [18]. The UNPRPD started in January 2019

128 in two Luapula province districts in Zambia and will end in December 2021. It aims to

129 increase HIV and sexual and reproductive health services among girls and women

130 with disabilities receiving SCT in two districts. We also collected data from two

131 districts in the same province not covered by the UNPRPD, but receiving SCT, to

132 provide comparators in the evaluation.

133 Households are eligible to receive the SCT if government authorities identify them as

134 extremely poor through measures of standards of living and satisfying one or more of

135 the following criteria: women-headed; headed by a person aged 65 years or older,

136 have a member with a disability; have adult members who are unable to work or

137 support themselves economically and host orphans and vulnerable children, i.e., any

138 child below 18 years who may be living with HIV, has lost one or both parents to HIV,

139 or from any cause, or lives in a community affected by HIV [19]. Eligible households

140 received ZMK90 (USD12) per month, and ZMK180 (USD24) if they included a

141 person with a disability. The payments were disbursed every two months through a

142 local pay point manager, the post office, or the recipients' bank account [19].

\section{Sample size calculation}

144 We calculated a minimum sample size of 1,800 households, from 90 community

145 welfare action committees (CWACs) which are political units, and 20 households per

146 CWAC. Our sample size calculation assumed a statistical significance ( $\alpha$ ) of 0.05 ,

147 power of $80 \%$ and Intra-class Correlation Coefficients (ICCs) (p) of 0.01 to 0.08 and

148 intervention effect $(\square)$ of at least 0.20 on HIV prevention services including condom

149 use [20]. We sampled respondents in two stages. In stage one, we sampled CWACs

150 using proportional probability sampling without replacement so CWACs with more

151 households and typically with more services would be more likely to be selected. In

152 stage two, from each CWAC, we sampled 25 households, instead of 20, to allow for

153 non-response.

\section{Procedures}

Trained fieldworkers first obtained and recorded consent from every respondent aged 16 years or older on the electronic tablets (thumbprints for oral, and signatures for written consents). They then administered a questionnaire in the area's local language on the electronic tablets installed with Open Data Kit software to the household head and all household members aged 16 years or older who consented. The survey contains questions on socio-demographic characteristics, self-rated poverty, health and well-being, mental health, school enrolment, disability status, proximity to health facilities, health access restrictions related to disabilities, health services, receipt of SCT offered by the government, non-governmental organizations and individuals, training, and MPA. We derived the questions from piloted and 
medRxiv preprint doi: https://doi.org/10.1101/2021.10.22.21264347; this version posted October 26, 2021. The copyright holder for this preprint (which was not certified by peer review) is the author/funder, who has granted medRxiv a license to display the preprint in perpetuity.

It is made available under a CC-BY-NC 4.0 International license .

166 Survey. We translated the questions from English into the local language. We trained the fieldworkers using role plays to ensure understanding and standardized administration of the questionnaire. We stored and electronically transferred the data to a secure server. We analyzed responses only from respondents aged 16 to 24 years.

The study protocol was reviewed by the University of Zambia Humanities and Social Sciences Research Ethics Committee (IRB Approval No. 2019-April-001) and the ethics committee in the Canton of Geneva (no 2019-00500).

\section{Measures and variables:}

We identified and three potential accelerators: 1) SCT, 2) LLL, and 3) MPA, and seven SDGs aligned indicator target outcomes in the data based on our review of the literature. We defined the accelerators as follows: SCT provided by the government with the question: "During the past 12 months, has the respondent or any household member received money or goods, including food, clothing, livestock, or medicines from any of the following government programmes, social cash transfers and other government transfers?" (Other government transfers combined respondents or their household's receipt of school uniforms, scholarships, food security pack, school feeding, and farm input subsidy), coded no, yes; LLL, combined participation in government offered training on HIV, disability, genderbased violence, human rights, sexual and reproductive rights, job skills, social protection and economic empowerment derived from the question: "During the past 12 months, have you or any of the household members received any training provided by the government on general health, food and nutrition, sexual and reproductive rights, HIV, human rights, and gender-based violence, social protection, job skills, and economic empowerment?" coded yes if the participant responded to have participated in any of the training, otherwise no; MPA with the question "What phone number is used at this house?" (Response options were no phone, phone number)" coded no for no phone, yes for phone number.

We defined the SDG aligned indicator outcomes as follows: No poverty with the question: "Do you consider your household to be nonpoor, moderately poor, or very poor?" coded very poor, moderately poor; Informal cash transfers with the question: "During the past 12 months, has the respondent or any household members received money or goods, including food, clothing, livestock, or medicines from individuals who are not part of the family or non-governmental organizations?" coded no, yes; Good health with the question: "Have you been sick or injured in the last two weeks?" coded physically sick, not sick; No suicidal ideation with the question: "Did you have thoughts of hurting or killing yourself? coded yes, no; Seeking mental support with the question "What health facility or other institutions or persons did you see for any of the identified mental health issues?" coded no did not see; yes saw. Seeking mental support proxied having mental health problems and seeking help to resolve them. School enrolment combined the responses from the question: "Are you currently attending school? (Check relevant choice) nursery/preschool, other grades full-time, other grades part-time, community school, full-time, correspondence, adult literacy class, tertiary school" coded no, yes. The proportion of adolescents currently in school versus those not in school for 20 to 24-year-olds, coded no, yes; No health access restrictions related to a disability with the 
medRxiv preprint doi: https://doi.org/10.1101/2021.10.22.21264347; this version posted October 26, 2021. The copyright holder for this preprint (which was not certified by peer review) is the author/funder, who has granted medRxiv a license to display the preprint in perpetuity.

It is made available under a CC-BY-NC 4.0 International license .

question: "Are you limited in accessing health services because of your impairment?" coded limited, not limited.

We controlled for age (16 to 19, 20 to 24 years), biological sex (male, female), disability status (not disabled, disabled), proximity to health facility $(<7$ or $\geq 7$ kilometres), and district (Kawambwa, Nchelenge, Mansa, and Samfya). We assessed household heads' disability with questions from the Washington Group Short Questions (WGSQ) on disabilities. The WGSQ asks respondents if they have difficulties with seeing, hearing, walking, cognition, self-care, or communicating. For each disability type, the answer options are "no"; "yes - a little"; "yes - a lot"; "cannot at all." We defined a respondent as disabled in the disability type they answered: "yes - a lot" or "cannot at all" and grouped the disability variables into a composite variable reflecting if the respondent had any of the six types of disability [21].

\section{Analysis}

We conducted analyses in three steps. First, we explored the socio-demographic characteristics, hypothesized accelerators and SDGs aligned outcomes by household head's disability status. Second, we tested for associations between each SDG-aligned outcome and hypothesized accelerators simultaneously using the Fishers exact test and reported crude proportions, 95\% confidence intervals $(\mathrm{Cl})$ and $\mathrm{p}$-values. We adjusted for covariates in multivariable logistic regressions and corrected for multiple hypothesis testing using the Benjamin, Yekutieli, Krieger (BYK) False Discovery Rate Sharpened Qs [22]. We interpreted the FDR adjusted p-value as a p-value of 0.05 , resulting in $5 \%$ of significant tests being false positives. FDR adjusted $p$-values result in fewer false positives than non-FDR adjusted $p$-values. Third, we predicted adolescents' probabilities of experiencing each outcome from no accelerators to cumulative accelerators combinations by household heads' disability status using marginal effects models with the Stata margins command keep other covariates at their mean values. We reported the changes in probabilities for each indicator.

As a sensitivity analysis, we calculated adjusted probabilities of experiencing each outcome from multiple-outcome probit models that correlated the error terms of three potential accelerators in each model, using the mvprobit command in Stata 14.1 set at 50 random draws. Each regression regressed one of the seven SDG aligned outcomes for adolescents on the three accelerators controlling for sociodemographic factors. We clustered analyses at the CWAC level and used Stata version 14.1 for analysis.

\section{Results:}

The sample comprised 1,725 adolescents from 1,545 households in 90 CWACs. Overall, $881(51.1 \%)$ were girls and $844(48.9 \%)$ boys. The median age in years was 19 (interquartile range 17 to 21). Eight per cent (145) of the adolescents lived with household heads with disabilities. Half $(75,51.7 \%)$ of household heads with disabilities reported at least "a lot" of difficulties in remembering, $43(29.6 \%)$ in seeing and $14(9.6 \%)$ in self-care. Many socio-demographic characteristics and SDG 
medRxiv preprint doi: https://doi.org/10.1101/2021.10.22.21264347; this version posted October 26, 2021. The copyright holder for this preprint (which was not certified by peer review) is the author/funder, who has granted medRxiv a license to display the preprint in perpetuity.

It is made available under a CC-BY-NC 4.0 International license .

259 aligned targets indicators differed significantly between adolescents living with household heads with and without disability; the three hypothesized accelerators did not differ.

[Insert Table 1 here]

The three hypothesized accelerators - SCT, LLL and MPA - were significantly associated with no poverty, informal cash transfers, good health, no suicidal ideation, school enrolment and no health access restrictions related to disabilities when we did not control for socio-demographic covariates. However, SCT was associated with lower levels of seeking mental support among adolescents (Table 2A). Adolescents with MPA, reported higher levels of no poverty (39\% versus $23.9 \%, p<0.001)$, accessing informal cash transfers $(26.6 \%$ versus $16 \%, \mathrm{p}<0.001)$, good health $(34.5 \%$ versus $30.2 \%, p=0.042)$, seeking mental support (38.4\% versus $26.9 \% ; p<0.000$ ) and school enrolment $(48.8 \%$ versus $39.7 \%, p<0.001)$ than those without MPA.

After adjusting for age, gender, household heads' disability status, distance from the nearest health facility and district, all hypothesized accelerators remained associated with two or more SDG-aligned outcomes (Table 2B). Good health and no suicidal ideation were no longer associated with any hypothesized accelerator. Having access to a mobile phone was associated with higher odds of no poverty, accessing informal cash transfers, seeking mental support and school enrolment. SCT were associated with higher odds of informal cash transfers, no health access restrictions related to disability but lower odds of seeking mental support. LLL was associated with increased odds of accessing informal cash transfers but lower odds of school enrolment.

[Insert Tables 2A and 2B here]

Figure 1 shows the changes in probabilities of experiencing each of the seven SDGaligned outcomes from potential accelerators compared to no accelerators: 1) SCT alone, 2) SCT plus LLL, 3) SCT plus MPA, 4) SCT, plus LLL and MPA. Results are stratified by disability status of the household head. Potential accelerators were associated with an absolute increase of at least 0.02 in the probability of SDG aligned targets indicators. However, the probability of seeking mental support was decreased by SCT alone, SCT plus LLL, and SCT plus MPA. The probability of school enrolment was also decreased by SCT plus LLL.

Adolescents with household heads with disabilities had lower probabilities of reporting no poverty, accessing informal cash transfers, good health and no suicidal ideation from no potential accelerators than their counterparts without household heads with disabilities. They further reported lower probability changes from potential accelerators in no poverty, accessing informal cash transfers, good health, and no health access restrictions related to disability. The probability increase in no suicidal ideation from potential accelerators was higher among adolescents living with 
medRxiv preprint doi: https://doi.org/10.1101/2021.10.22.21264347; this version posted October 26, 2021. The copyright holder for this preprint (which was not certified by peer review) is the author/funder, who has granted medRxiv a license to display the preprint in perpetuity.

It is made available under a CC-BY-NC 4.0 International license .

298 household heads with disabilities. Changes in seeking mental support and school 299 enrolment did not differ by the disability status of the household head. The greatest 300 probability changes from receiving no potential accelerators to receiving potential 301 accelerators were in accessing informal cash transfers (Figure 1).

[Insert Figure 1 here]

304

Synergies - combinations - of potential accelerators were associated with changes in the probabilities of experiencing levels of SDG-aligned targets indicators outcomes for adolescents living with household heads with and without disabilities. A combination of all potential accelerators - SCT, LLL and MPA - was associated with a 0.15 and 0.11 probability increase in levels of no poverty for adolescents living with household heads without and with disabilities; 0.37 and 0.30 probability increase in levels of accessing informal cash transfers and 0.14 and 0.13 of experiencing no health access restrictions related to a disability, respectively (Figure 2).

The sensitivity analysis results between the models we used and the models that account for correlations between the error terms of the potential accelerators were equivalent. However, the p-values were lower in the outcome models accounting for the correlation between potential accelerators (Supplementary Table 1).

\section{Discussion}

This study examined associations between potential accelerators - SCT, LLL, and MPA - and SDG aligned well-being indicator targets - 1.2 no poverty; 1.3.1 SCT, Informal cash transfers; 3.0 good Health; 3.4 no suicidal ideation, seeking mental support; 4.1 school enrolment; and 10.0 no health access restrictions related to disability - among adolescents. We found high potential for improving vulnerable adolescents' SDG-aligned well-being by combining SCT, LLL and MPA interventions. Our findings fit within an emerging body of evidence confirming that SCT, LLL and MPA are accelerators for adolescents [8,10,13]. It further found that adolescents benefited unequally depending on their household heads' disability status and that combining existing interventions may not overcome inequalities arising out of the disability of the household head.

Several studies conducted in Zambia and elsewhere confirm our results that SCT were associated with multiple SDG aligned target outcomes such as higher levels of informal cash transfers, no health access restrictions related to disability, and lower levels of seeking mental support. Studies conducted in Zambia show that SCT reduced relative poverty, increased women's satisfaction regarding their children's well-being, and schooling among school-going adolescents [23,24]. SCT also increased material well-being (children's material needs met), food insecurity, and 
medRxiv preprint doi: https://doi.org/10.1101/2021.10.22.21264347; this version posted October 26, 2021. The copyright holder for this preprint (which was not certified by peer review) is the author/funder, who has granted medRxiv a license to display the preprint in perpetuity.

It is made available under a CC-BY-NC 4.0 International license .

asset ownership [25]. In sub-Sahara Africa and elsewhere, SCT have been shown to increase psychological well-being, and decrease relative and absolute poverty $[26,27]$. In our study, receiving SCT alone was associated with a substantial decrease in seeking mental support. Combining SCT with LLL or MPA was associated with more reductions in seeking mental support. This result suggests that households' lack of money, LLL opportunities, and MPA may have necessitated respondents to seek mental support. Providing SCT, LLL and MPA interventions may be vital for addressing the mental support needs of adolescents living in poverty.

However, in our study SCT were not associated with good health; neither were MPA and LLL. This result fits within a body of evidence showing that cash transfers have positive, complex, and mixed effects on health. A review of 56 studies from low and middle-income countries found that cash transfers increased dietary diversity, access and utilization of health services but had little impact on children's anthropometric measures [26]. In high-income countries, self-rated health, chronic health conditions, and mortality for cash transfer recipients were worse than among non-recipients. On the contrary, in the United States, cash transfers were associated with improved self-rated health [28]. One reason why SCT, MPA, and LLL in our study were not associated with good health could be that physical illnesses among our sample was widespread. Two-thirds $(67.8 \%, n=1169)$ of adolescents reported physical illnesses. Another is that malaria is endemic in the study area [29]. SCT, MPA and LLL alone might have been insufficient to resolve these illnesses. Innovative prevention and treatment of malaria, and other illnesses, combined with SCT, MPA, and LLL, should be implemented.

Contrary to views that cash transfers and other public transfers reduce informal transfers [30], our study found the opposite result; SCT were associated with increased receipt of informal cash transfers. This result is supported by evidence $[31,32]$. One explanation for our study's finding is that the process of receiving SCT may have identified households who were in need of financial and material support, linked them to support, strengthened trust of each other, increased social inclusion and solidarity [31-33]. Another explanation is that our study did not include pensions and social security transfers analyzed in the study that found contradictory findings to our study results [30]. Pensions and social security transfers, derived from mandatory savings employees make during employment, tend to be larger than SCT. In addition, pensions and social security transfers recipients may be wealthier, making them less likely to be perceived as in need of informal cash transfers [31].

The positive associations found in our study between MPA and no poverty, informal cash transfers, and school enrolment are also supported by evidence [8,34]. Access to mobile phones can promote adolescents' wellbeing, expand their social networks and personal growth opportunities [8]. Social protection and cash transfers are being delivered via mobile phones, alongside electronic vouchers, bank accounts and other payment systems to adults in households [35]. Mobile phones use also enables access to vital services [8,34]. Informal financial transfers make the bulk of financial transactions transferred via mobile phones in sub-Sahara Africa [36]. The negative association found in our study between MPA and seeking mental support 
medRxiv preprint doi: https://doi.org/10.1101/2021.10.22.21264347; this version posted October 26, 2021. The copyright holder for this preprint (which was not certified by peer review) is the author/funder, who has granted medRxiv a license to display the preprint in perpetuity.

It is made available under a CC-BY-NC 4.0 International license .

384 suggests that lack of mobile phone access may be mentally distressing for

385 adolescents. One main reason is that they may miss out on informal cash transfers

386 and other services to improve their well-being $[8,34,36]$. Providing mobile phones to

387 households who do not have them, is being done and can help improve adolescents

388 access to social protection, cash transfers and mental support [35].

389 In our study, LLL's associations - increase in informal cash transfers, and reductions

390 in odds of seeking mental support and school enrollment - are limited than those of

391 SCT and MPA, but no less critical. LLL re-enforces and complements the objectives

392 of social protection and cash transfer programmes. LLL may bring participants

393 together, potentially increasing their social networks - addressing the needs to seek

394 mental support - and informal cash transfers. LLL is unlikely to have pulled

395 adolescents out of school. Two-thirds of adolescents were already not attending

396 school. LLL and the skills it provides can be beneficial to these adolescents [37].

Adolescents did not evenly benefit from SCT alone, with LLL, MPA or LLL and MPA, although they benefited from these accelerators. Adolescents living with household heads with disabilities reported lower benefits from these accelerators in no poverty, informal cash transfers, good health, and no disability health access restrictions than those living with household heads without disabilities. Previous studies, including a systematic review, support this finding showing that living with a household member with a disability had high cost and poverty implications for the household $[38,39]$. These studies concluded that households must spend as much as $26 \%$ more resources to obtain an equivalent standard of living compared to those without disabilities [38,39]. Adolescents in our sample living with household heads with disabilities reported themselves poorer, may have had much more diminished resources and saddled with caregiving responsibilities adversely affecting their wellbeing than their peers living with household heads without disabilities. However, adolescents living with household heads with disabilities reported greater benefits from accelerators in no suicidal ideation. Their probabilities of reporting no suicidal ideation from no accelerators were lower compared to their peers without household heads with disabilities. This result suggests that household heads' disability status may have mitigated suicidal ideation among adolescents. Such adolescents might have benefited from parental supervision during caregiving which is known to be protective against suicidal behaviour [40]. However, this study did not look at the role of the household head's disability status on adolescents' suicidal ideation. Overall, accelerators appear to impact adolescents' well-being. However, adolescents living with household heads with disabilities were doing worse than their peers living with household heads without disabilities before and after the accelerators. New interventions focused at households may be required. These could include attention to adolescents and parents' relationships, increased psychosocial, mental and financial support to offset adolescents' household's disabilities-related inequalities [38].

\section{Limitations}

It is important to note that association does not imply causal relationships. In this study we could not attribute causation due to the study's cross-sectional nature, and 


(1)

neither could we generalize the results outside the study area and population group.

However, many countries in sub-Saharan Africa are implementing similar programmes and could find our results useful in their contexts. We performed a complete sample analysis due to the low prevalence of disability in our sample, which might have missed nuanced differences experienced by adolescent girls compared to boys. The prevalence of disability in our sample was low limiting our ability for further analysis by type of disability. We did not have variables on occupational type of the household head, and others which could affect household dynamics including adolescents' well-being. We did not input the missing data because it was less than $5 \%$. However, we show that adopting accelerators can help achieve SDGs-aligned well-being indicators for adolescents living in poverty.

\section{Conclusion}

Our study found multiple and substantial benefits from accelerators - SCT, LLL and MPA - delivered individually and in combinations, on SDG aligned well-being among adolescents living in poverty. Adolescents living with household heads with disabilities benefited less. New interventions maybe necessary to correct disabilityrelated inequalities between households. More research is needed to understand combinations of interventions that improve the well-being of adolescents living with household members who are disabled.

\section{Funding}

The authors declare that this study received funding from United Kingdom Research in Innovation (UKRI) Global Challenges Research Fund (GCRF) Accelerating Achievement for Africa's Adolescents Hub (Principle Investigator Prof. Lucie Cluver). The funder was not involved in the study design, collection, analysis, interpretation of data, the writing of this article or the decision to submit it for publication.

4

5

6

7

8

9

0




\section{References}

1. United Nations Department of Economic and Social Affairs (UNDESA). World Population Prospects 2019: Highlights. New York: United Nations, Department of Economic and Social Affairs; 2019. Report No.: (ST/ESA/SER.A/423)..

2. Sawyer SM, Peter SA, Dakshitha W, George P. The age of adolescence. The Lancet Child and Adolescent Health. 2018 March; 2(3): 223-228.

3. World Health Organization (WHO). Guidelines on mental health promotive and preventive interventions for adolescents: helping adolescents thrive. Geneva: World Health Organization; 2020. Report No.: CC BY-NC-SA 3.0 IGO.

4. World Health Organization (WHO). Adolescent and young adult health. [Online].; 2021 [cited 2021 February 5. Available from: https://www.who.int/news-room/factsheets/detail/adolescents-health-risks-and-solutions.

5. Uddin R, Burton NW, Maple M, Khan SR, Khan A. Suicidal ideation, suicide planning, and suicide attempts among adolescents in 59 low-income and middle-income countries: a population-based study. Lancet Child Adolescent Health. 2019 Apr; 3(4)(doi: 10.1016/S2352-4642(18)30403-6.): 223-233..

6. Dickens L, Marx P. NEET as an Outcome for Care Leavers in South Africa: The Case of Girls and Boys Town. Emerging Adulthood. 2020; 8(1 https://doi.org/10.1177/2167696818805891): 64-72.

7. International Labour Organisation (ILO). Global Employment Trends for Youth 2020: Technology and the future of jobs. Geneva: International Labour Organisation, International Labour Office; 2020.

8. Porter G, Hampshire K, Lannoy AD, Bango A, Munthali A, Robson E, et al. Youth Livelihoods in the Cellphone Era: Perspectives from Urban Africa. Journal of International Development. 2018 January; 30(DOI: 10.1002/jid.3340): 539-558.

9. International Telecommunication Union (ITU). Mobile-cellular Subscriptions Declining in 2020. [Online].; 2021 [cited 2021 February 2. Available from: https://www.itu.int/en/ITUD/Statistics/Pages/ff2020interactive.aspx.

10. Desmond C, Sherr L, Cluver L. Covid-19: accelerating recovery. Vulnerable Children and Youth Studies. 2020. May;(DOI: 10.1080/17450128.2020.1766731).

11. United Nations Development Programme (UNDP). SDG Accelerator and Bottleneck Assessment tool. New York: United Nations Development Programme, Sustainable Development Cluster, 
medRxiv preprint doi: https://doi.org/10.1101/2021.10.22.21264347; this version posted October 26, 2021. The copyright holder for this preprint (which was not certified by peer review) is the author/funder, who has granted medRxiv a license to display the preprint in perpetuity.

It is made available under a CC-BY-NC 4.0 International license .

UNDP Bureau for Policy; 2017.

12. Cluver LD, Orkin FM, Meinck F, Yakubovich AR, Sherr L. Can Social Protection Improve SustainableDevelopment Goals for Adolescent Health? PLOS ONE. 2016 October;(e0164808.doi:10.1371/journal. pone.0164808): 11(10).

13. Cluver LD, Orkin FM, Campeau L, Toska E, Webb D, Carlqvist A, et al. Improving lives by accelerating progress towards the UN Sustainable Development Goals for adolescents living with HIV: a prospective cohort study. Lancet Child Adolescence. 2019 April; 3(https://doi.org/10.1016/S2352-4642(19)30033-1): 245-54.

14. Cluver LD, Rudgard WE, Toska E, Zhou S, Campeau L, Shenderovich Y, et al. Violence prevention accelerators for children and adolescents in South Africa: A path analysis using two pooled cohorts. PLoS Medicine. 2020 November; e1003383(https://doi.org/10.1371/journal.pmed.1003383): 17(11).

15. Nations U. Disability and Development Report. Realizing the Sustainable Development Goals by, for and with persons with disabilities 2018. New York: United Nations, Department of Economic and Social Affairs ; 2019. Report No.: 9789210479035 (PDF).

16. WHO, World Health Organization. WHO global disability action plan 2014-2021. Better health for all people with disability. Geneva: WHO, World Health Organization; 2015. Report No.: ISBN 978 9241509619.

17. Devereux S, Vincent K. Using Technology to Deliver Social Protection: Exploring Opportunities and Risks. In http://www.jstor.org/stable/27806713, editor. Development in Practice 20, no. 3.; 2010. p. 367-79.

18. United Nations Partnership on the Rights of Persons with Disabilities. http://unprpd.org/ourprogrammes/78. [Online].; 2020 [cited 2020 August 2020 10. Available from: http://unprpd.org/our-programmes/78.

19. Ministry of Community Development and Social Service, Government of the Republic of Zambia. Social Cash Transfers, Investing investing in People's lives, transforming communities, Social Cash Transfer Guidelines. Guidelines. Lusaka: Ministry of Community Development and Social Service; 2018.

20. Handa S, Hoop Td, Morey M, Seidenfeld D. ICC Values in International Development: Evidence across Many Domains in subSaharan Africa..

21. Washington Group on Disability Statistics. The Data Collection Tools Developed by the Washington Group on Disability Statistics and their Recommended Use. Hyattsville: United Nations Statistical Comission, Washington Group on Disability Statistics; 23 October 2017.

22. Anderson ML. Multiple Inference and Gender Differences in the Effects of Early Intervention: A Reevaluation of the Abecedarian, Perry Preschool, and Early Training Projects. Journal of the American Statistical Association. 2008; 103(484 https://doi.org/10.1198/016214508000000841): 1481-1495.

23. Sudhanshu H, Luisa N, David S, Gelson T, Benjamin D. Can unconditional cash transfers raise 
medRxiv preprint doi: https://doi.org/10.1101/2021.10.22.21264347; this version posted October 26, 2021. The copyright holder for this preprint (which was not certified by peer review) is the author/funder, who has granted medRxiv a license to display the preprint in perpetuity. It is made available under a CC-BY-NC 4.0 International license .

long-term living standards? Evidence from Zambia. Journal of Development Economics. 2018 July; 133(doi.org/10.1016/j.jdeveco. 2018.01.008): 42-65.

24. Hjelma L, Handa S, de Hoop J, Palermo T. Poverty and perceived stress: Evidence from two unconditional cash transfer programs in Zambia. Social Science \& Medicine. 2017 March; 177(https://doi.org/10.1016/j.socscimed.2017.01.023): 110-117.

25. Natalia LHS, Peterman A, Seidenfeld D, Tembo G. Does money buy happiness? Evidence from an unconditional cash transfer in Zambia. SSM - Population Health. 2018 April; 4(https://doi.org/10.1016/j.ssmph.2018.02.002): 225-235.

26. Bastagli F, Hagen-Zanker J, Harman L, Barca V, Sturge G, Schmidt T, et al. Cash transfers: what does the evidence say? A rigorous review of programme impact and of the role of design and implementation features. London: Overseas Development Institute (ODI); 2016.

27. Haush ofer J, Mudida R, Shapiro JP. The Comparative Impact of Cash Transfers and a Psychotherapy Program on Psychological and Economic Well-being Research NBoE, editor. Cambridge Mass: National Bureau of Econmic Research; 2020.

28. Sun S, Huang J, Hudson DL. Cash Transfers and Health. Annual Review of Public Health. 2021 January; 42: 363-80.

29. Ministry of Health, Government of the Republic of Zambia. Zambia National Malaria Indicator Survey. Lusaka: Ministry of Health, Ministry of Health, Central Statistics Office; 2018.

30. Nikolov P, Bonci M. Do Public Program Benefits Crowd Out Private Transfers in Developing Countries? A Critical Review of Recent Evidence. World Development. 2020 October; 134(104967).

31. Evans DK, Kosec K. Do Cash Transfers Reduce Trust and Informal Transfers? IFPRI Discussion Paper. Washington, DC: International Food Policy Research Institute (IFPRI), Development Strategy and Governance Division; 2020. Report No.: 01994.

32. Martin Evans SHaHS. Informal taxes and transfers in sub-Saharan Africa: A review and analysis of incidence in Rwanda. Working paper. London: Overseas Development Institute (ODI), December; 2020. Report No.: 598.

33. Asfaw S, Davis B. Can Cash Transfer Programmes Promote Household Resilience? Cross-Country Evidence from Sub-Saharan Africa. In Lipper L. MN,ZD,AS,BG, editor. Climate Smart Agriculture. Natural Resource Management.: Springer Cham; 2018. p. 227-250.

34. Giovanelli A, Ozer EM, DahI RE. Leveraging Technology to Improve Health in Adolescence: A Developmental Science Perspective. Journal of Adolescent Health. 2020 August 2020; 67(2: DOI:https://doi.org/10.1016/j.jadohealth.2020.02.020): S7eS13.

35. Barca V, Hurrell A, MacAuslan I, Visram A, Willis J. Paying attention to detail: how to transfer cash in cash transfers. Enterprise Development and Microfinance. 2003 March; 24(1).

36. Koomson I, Bukari C, AVillano R. Mobile money adoption and response to idiosyncratic shocks: Empirics from five selected countries in sub-Saharan Africa. Technological Forecasting and Social 
medRxiv preprint doi: https://doi.org/10.1101/2021.10.22.21264347; this version posted October 26, 2021. The copyright holder for this preprint

(which was not certified by peer review) is the author/funder, who has granted medRxiv a license to display the preprint in perpetuity.

It is made available under a CC-BY-NC 4.0 International license.

Change. 2021 167; 167(120728).

37. Ministry of Education. Educational Statistical Bulletin 2017. Statistical Bulletin. Lusaka: Ministry of Education, Republic of Zambia, Directorate of Planning and Information; 2018.

38. Mitra S, Palmer M, Kim H, Mont D, Groce N. Extra costs of living with a disability: A review and agenda for research. Disability and Health Journal. 2017 October; 10(4): 475 - 484.

39. Asuman D, Ackah CG, Agyire-Tettey F. Disability and Household Welfare in Ghana: Costs and Correlates. Journal of Family and Economic Issues. 2020 December; (https://doi.org/10.1007/s10834-020-09741-5).

40. Kushal SA, Amin YM, Reza S, Shawon MSR. Parent-adolescent relationships and their associations with adolescentsuicidal behaviours: Secondary analysis of data from 52 countries usingthe Global School-based Health Survey. EClinical Medicine. 2020 December;(doi.org/10.1016/j.eclinm.2020.100691). 
Table 1: Social demographic characteristics, hypothesized accelerators and SDG-aligned targets by disability status of the household head

\begin{tabular}{lccccc} 
& not disabled & disabled & P-value & Total & $\%$ \\
Variables & $n=1580$ & $\%$ & $n=145$ & $\%$ & \\
1725 & \\
\hline
\end{tabular}

Socio-demographic characteristics

$\begin{array}{rrrrrrrr}\text { Age (years) } 16-19 & 951 & 60.2 & 67 & 46.2 & & 1018 & 59.0 \\ 20-24 & 629 & 39.8 & 78 & 53.8 & 0.001 & 707 & 41.0 \\ & & & & & & & \\ \text { Sex, Male } & 787 & 49.8 & 57 & 39.3 & & 844 & 48.9 \\ \text { Female } & 793 & 50.2 & 88 & 60.7 & 0.015 & 881 & 51.1\end{array}$

Distance to nearest the health facility (kilometres) $0-6$

$\begin{array}{lll}1291 & 81.7 \quad 121\end{array}$

7 and over Missing

District Kawambwa Mansa Nchelenge Samfya

\section{$242 \quad 15.3$}

$\begin{array}{ll}47 & 3.0\end{array}$

$502 \quad 31.8$

$\begin{array}{ll}311 & 19.7\end{array}$

$378 \quad 23.9$

$389 \quad 24.6$
121

$\begin{array}{ll}19 & 13.1\end{array}$

$5 \quad 3.4$

0.489

$1412 \quad 81.9$

$\begin{array}{ll}261 & 15.1\end{array}$

$\begin{array}{ll}52 & 3.0\end{array}$

$\begin{array}{ll}557 & 32.3\end{array}$

$333 \quad 19.3$

$409 \quad 23.7$

$55 \quad 37.9$

$22 \quad 15.2$

$426 \quad 24.7$

Hypothesized accelerators

\begin{tabular}{rrlrllrl} 
SCT No & 157 & 9.9 & 15 & 10.3 & & 172 & 10.0 \\
Yes & 1408 & 89.1 & 128 & 88.3 & & 1536 & 89.0 \\
Missing & 15 & 0.9 & 2 & 1.4 & 0.862 & 17 & 1.0 \\
& & & & & & & \\
MPA No & 1081 & 68.4 & 101 & 69.7 & & 1182 & 68.5 \\
Yes & 499 & 31.6 & 44 & 30.3 & 0.759 & 543 & 31.5 \\
& & & & & & & \\
& & & & & & & \\
LLL No & 868 & 54.9 & 68 & 46.9 & & 936 & 54.3 \\
Yes & 697 & 44.1 & 75 & 51.7 & 0.069 & 772 & 44.8 \\
Missing & 15 & 0.9 & 2 & 1.4 & & 17 & 1.0 \\
\hline
\end{tabular}


SDG aligned target indicators

SDG 1.2. No poverty Very poor

Moderately poor

110369.8

$115 \quad 79.3$

$1218 \quad 70.6$

Missing

$462 \quad 29.2$

$28 \quad 19.3$

0.012

$490 \quad 28.4$

21.4

$17 \quad 1.0$

SDG 1.3.1 Informal cash

transfers No

Yes

$\begin{array}{ll}1260 & 79.7\end{array}$

$118 \quad 81.4$

$1378 \quad 79.9$

Missing

$305 \quad 19.3$

$\begin{array}{ll}25 & 17.2\end{array}$

0.561

$330 \quad 19.1$

21.4

$17 \quad 1.0$

SDG 3. Good health

Physically sick

Not sick

$1062 \quad 67.2$

$107 \quad 73.8$

$\begin{array}{ll}36 & 24.8\end{array}$

2 2 1.4

$1169 \quad 67.8$

Missing

$\begin{array}{ll}15 & 0.9\end{array}$

0.086

$\begin{array}{ll}539 & 31.2\end{array}$

$17 \quad 1.0$

SDG 3.4. No suicidal ideation

$\begin{array}{rrlrlrrl}\text { Yes } & 156 & 9.9 & 29 & 20.0 & & 185 & 10.7 \\ \text { No } & 1404 & 88.9 & 114 & 78.6 & 0.000 & 1518 & 88.0 \\ \text { Missing } & 20 & 1.3 & 2 & 1.4 & & 22 & 1.3\end{array}$

SDG 3.4. Seeking mental

support No

108768.8

$100 \quad 69.0$

$1187 \quad 68.8$

Yes

$479 \quad 30.3$

$\begin{array}{ll}43 & 29.7\end{array}$

$\begin{array}{ll}522 & 30.3\end{array}$

Missing

$\begin{array}{ll}14 & 0.9\end{array}$

25

$\begin{array}{ll}16 & 0.9\end{array}$

SDG 4.1. School enrolment

$\begin{array}{rllllllll}\text { No } & 901 & 57.0 & & 89 & 61.4 & & 990 & 57.4 \\ \text { Yes } & 678 & 42.9 & & 56 & 38.6 & 0.314 & 734 & 42.6\end{array}$

SDG 10. No health access restrictions related to disability

Limited

$243 \quad 15.4$

$21 \quad 14.5$

15.3

Not limited

$1290 \quad 81.6$

$\begin{array}{ll}119 & 82.1\end{array}$

0.791

140981.7

Missing

$\begin{array}{ll}47 & 3.0\end{array}$

$\begin{array}{ll}5 & 3.4\end{array}$

$\begin{array}{ll}52 & 3.0\end{array}$

$p$-value is for Fisher's exact test 
medRxiv preprint doi: https://doi.org/10.1101/2021.10.22.21264347; this version posted October 26, 2021. The copyright holder for this preprint (which was not certified by peer review) is the author/funder, who has granted medRxiv a license to display the preprint in perpetuity. It is made available under a CC-BY-NC 4.0 International license.

502 
Table 2A: Crude analysis of associations between hypothesized accelerators and SDG aligned targets

\begin{tabular}{|c|c|c|c|c|c|c|}
\hline \multirow[b]{3}{*}{ SGD-aligned targets } & \multicolumn{6}{|c|}{ Hypothesized accelerators, absolute values [proportions], p-value } \\
\hline & \multicolumn{2}{|r|}{ SCT } & \multicolumn{2}{|c|}{ LLL } & \multicolumn{2}{|c|}{ MPA } \\
\hline & Yes & No & Yes & No & Yes & No \\
\hline 1.2. No poverty & 442 [28.8\%], & 46 [26.7\%]; 0.318 & 207[26.8\%], & 281 [30.1\%]; 0.074 & $212[39.0 \%]$ & $278[23.9 \%] ;<0.001$ \\
\hline $\begin{array}{l}\text { 1.3.1 Informal } \\
\text { cash transfers }\end{array}$ & 323 [21.0\%], & $7[4.7 \%] ;<0.001$ & $228[29.5 \%]$ & $102[10.9 \%] ;<0.001$ & $144[26.6 \%]$ & $186[16.0 \%] ;<0.001$ \\
\hline 3. Good health & 489 [31.8\%], & 50 [29.7\%]; 0.258 & $253[32.8 \%]$, & 285 [30.5\%]; 0.168 & $187[34.5 \%]$, & 352 [30.2\%]; 0.042 \\
\hline $\begin{array}{l}\text { 3.4. No suicidal } \\
\text { ideation }\end{array}$ & $1381[90.2 \%]$ & 137 [79.7\%]; <0.001 & $674[87.6 \%]$ & 843 [90.4\%]; 0.044 & $475[87.6 \%]$ & 1043 [89.8\%]; 0.102 \\
\hline $\begin{array}{r}\text { 3.4 Seeking } \\
\text { mental support }\end{array}$ & 447 [29.1\%], & 75 [43.6\%]; <0.001 & $278[36.0 \%]$ & $244[26.1 \%] ;<0.001$ & $208[38.4 \%]$ & $314[26.9 \%] ;<0.001$ \\
\hline $\begin{array}{r}\text { 4.1. School } \\
\text { enrolment }\end{array}$ & $662[43.1 \%]$ & 65 [37.8\%]; 0.103 & $302[39.1 \%]$ & $424[45.4 \%] ; 0.005$ & $265[48.8 \%]$ & 469 [39.7\%]; <0.001 \\
\hline $\begin{array}{r}\text { 10. No health } \\
\text { restrictions related to } \\
\text { disability }\end{array}$ & $1293[85.8 \%]$ & $116[69.9 \%] ;<0.001$ & $613[82.0 \%]$, & 795 [86.0\%]; 0.014 & 453[83.9\%], & 956 [84.4\%]; 0.425 \\
\hline
\end{tabular}

Fisher's exact test. 
medRxiv preprint doi: https://doi.org/10.1101/2021.10.22.21264347; this version posted October 26, 2021. The copyright holder for this preprint (which was not certified by peer review) is the author/funder, who has granted medRxiv a license to display the preprint in perpetuity.

It is made available under a CC-BY-NC 4.0 International license .

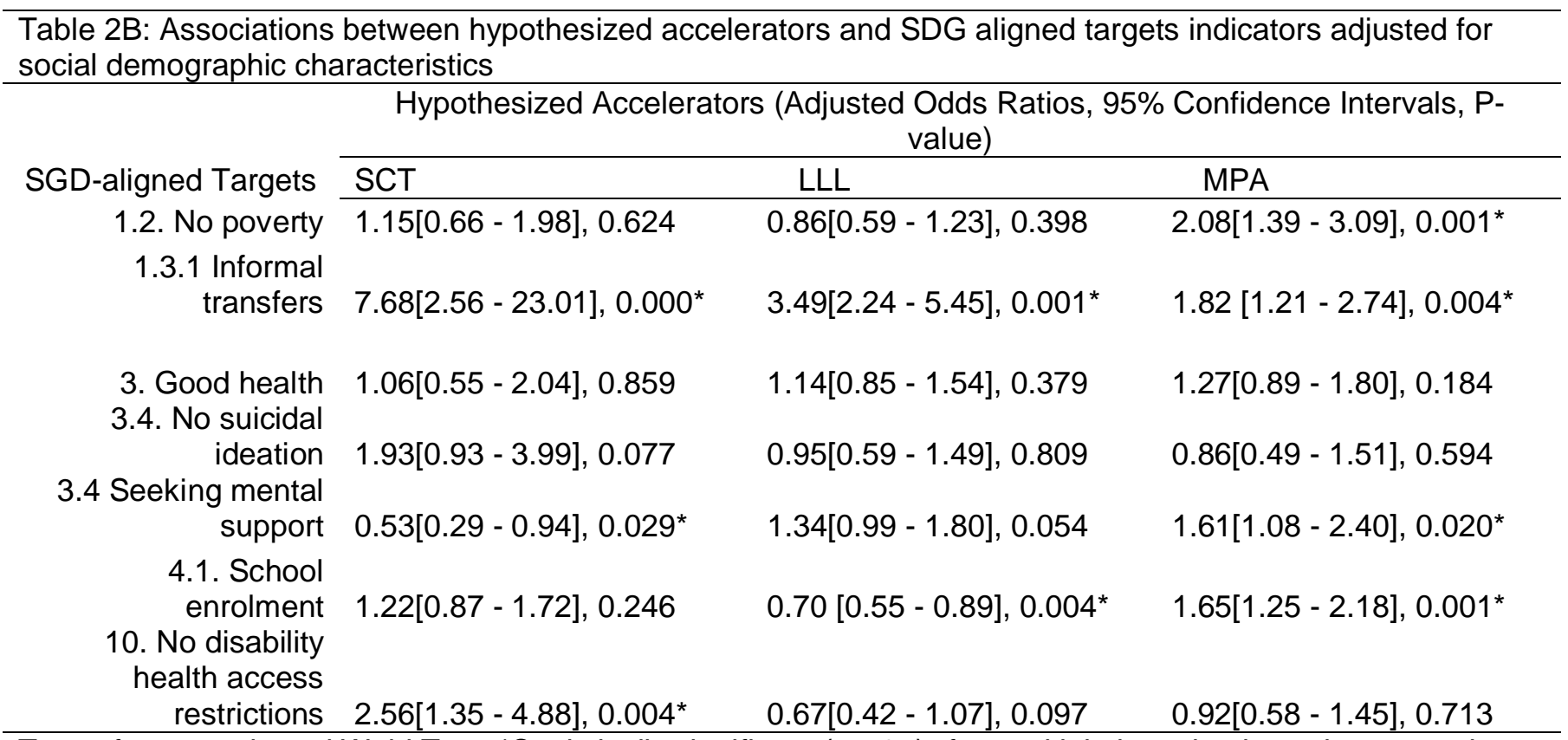

Type of test conducted Wald Test. *Statistically significant $(p<.05)$ after multiple hypothesis testing correction with the FDR sharpened Qs. Adjusted for age, gender, household head disability status, distance to the nearest health facility and district. 
medRxiv preprint doi: https://doi.org/10.1101/2021.10.22.21264347; this version posted October 26, 2021. The copyright holder for this preprint (which was not certified by peer review) is the author/funder, who has granted medRxiv a license to display the preprint in perpetuity.

$$
\text { It is made available under a CC-BY-NC } 4.0 \text { International license. }
$$




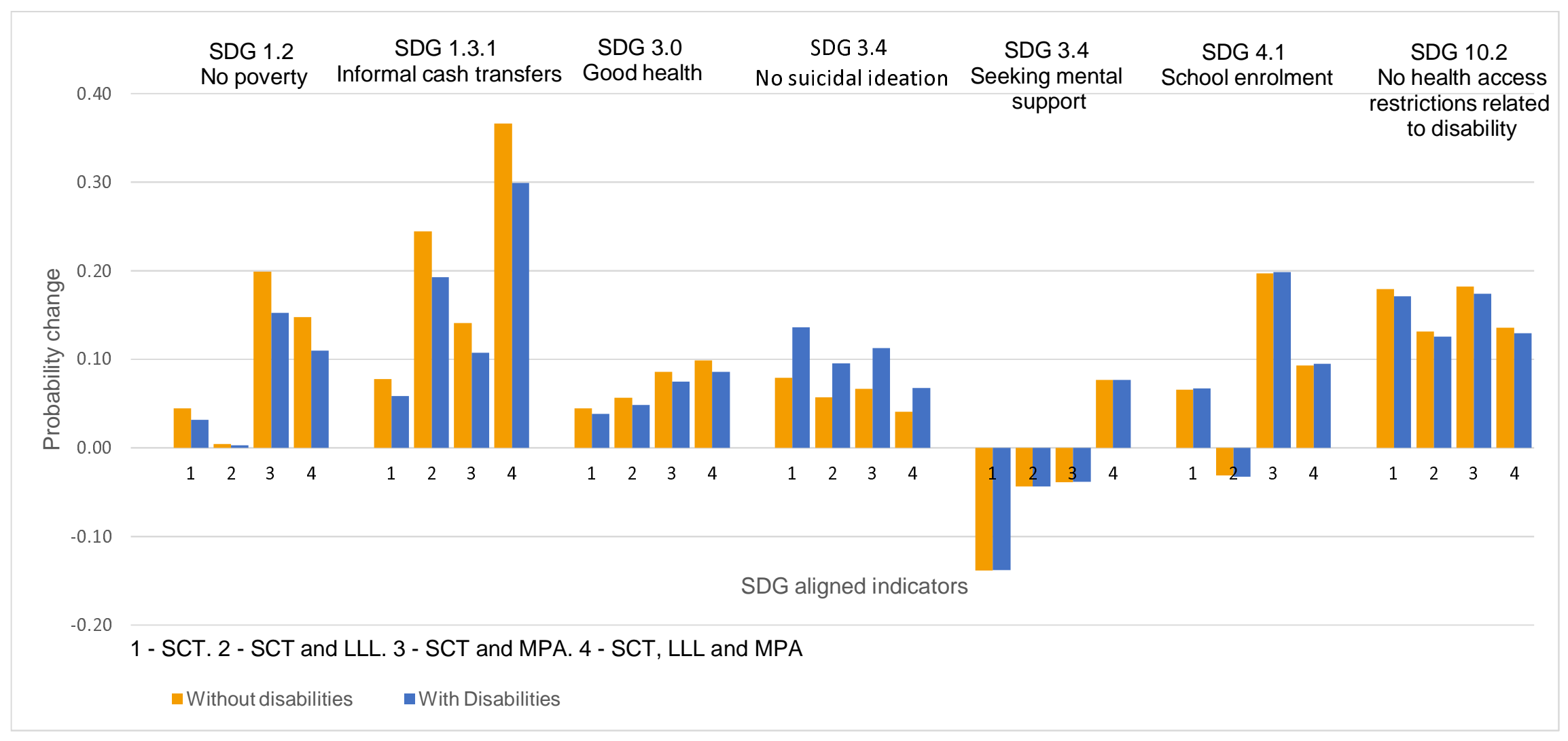

Figure 1: Levels of probability change in SDG-aligned targets indicators outcomes from 1) SCT alone, 2) SCT plus LLL 3) SCT plus MPA, and 4) SCT plus LLL and MPA, stratified by household heads' disability status - without (blue bars) and with disabilities (Orange bars). 
(A) Without disabilities

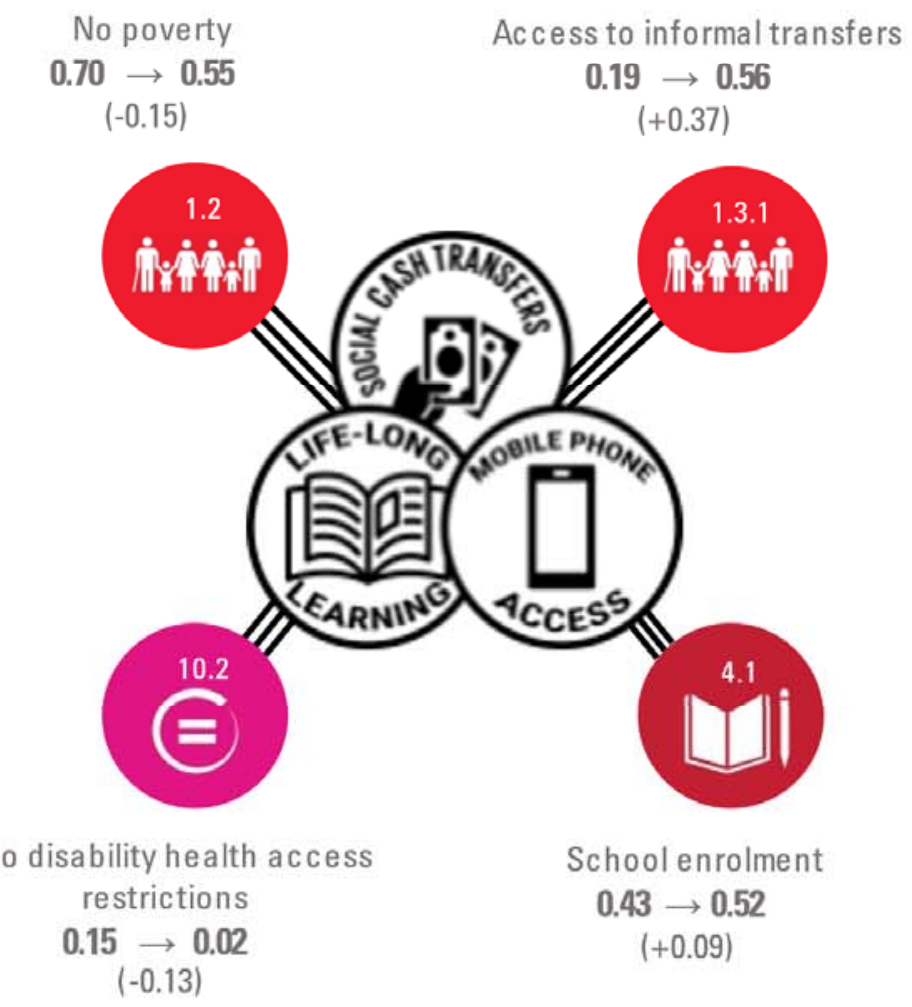

(B) With disabilities

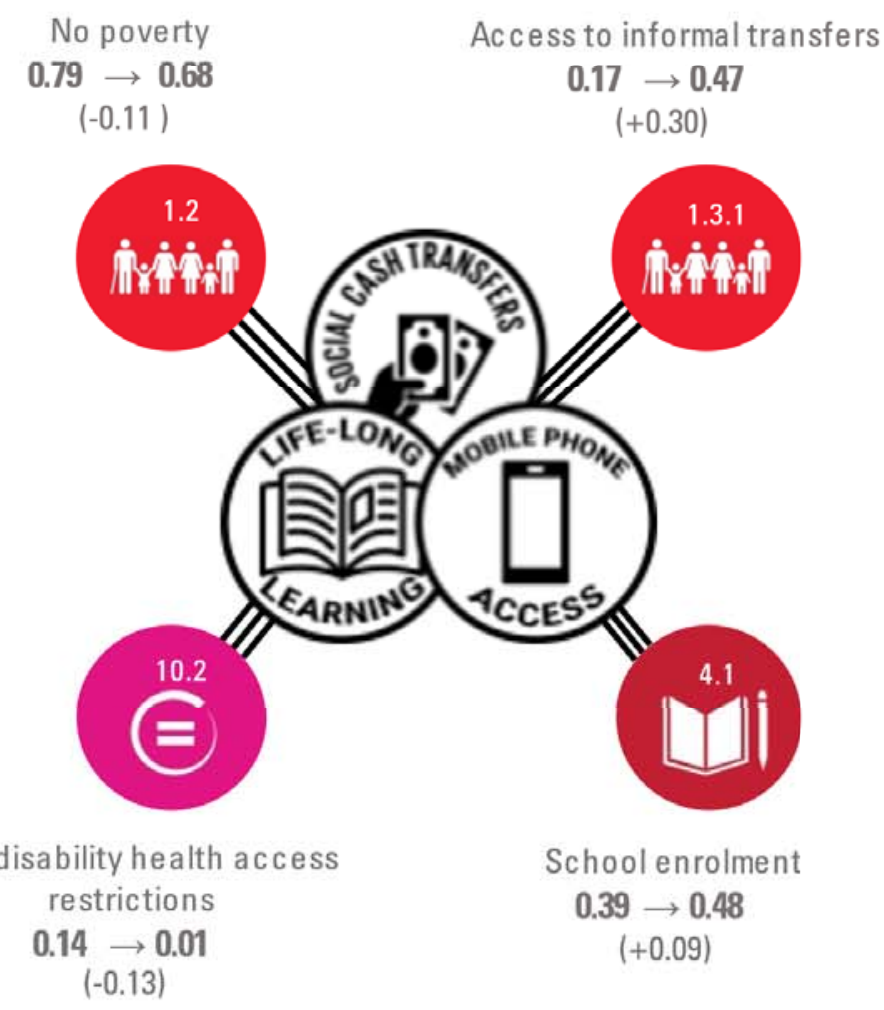

Figure 2: Changes in probability levels of SDG-aligned outcomes for adolescents living with household heads without (A) and with disabilities (B) from synergies of interventions. 


\begin{tabular}{|c|c|c|c|}
\hline \multicolumn{4}{|c|}{$\begin{array}{l}\text { Supplementary Table 1: Associations between hypothesized accelerators and SDG aligned targets using probit } \\
\text { models }\end{array}$} \\
\hline \multirow[b]{2}{*}{ SGD-aligned targets } & \multicolumn{3}{|c|}{ Hypothesized accelerators, Coefficient [95\% Cl], P-value } \\
\hline & SCT & LLL & MPA \\
\hline 1.2. No poverty & 0.15 [-0.08-0.37], 0.197 & $-0.14[-0.27--0.01], 0.043$ & $0.44[0.30-0.57],<0.001$ \\
\hline $\begin{array}{r}\text { 1.3.1 Informal cash } \\
\text { transfers }\end{array}$ & $0.80[0.44-1.17],<0.001$ & $0.66[0.51-0.81],<0.001$ & $0.35[0.20-0.50],<0.001$ \\
\hline 3. Good health & $0.14[-0.08-0.36], 0.215$ & $0.04[0-.09-0.17], 0.549$ & $0.13[-0.01-0.26], 0.064$ \\
\hline $\begin{array}{r}\text { 3.4. No suicidal } \\
\text { ideation }\end{array}$ & $0.44[0.20-0.69],<0.001$ & $-0.17[-0.33--0.01], 0.048$ & $-0.08[-0.26-0.09], 0.342$ \\
\hline $\begin{array}{r}\text { 3.4 Seeking mental } \\
\text { support }\end{array}$ & $-0.44[-0.65--0.23],<0.001$ & $0.29[0.16-0.42],<0.001$ & $0.31[0.18-0.45],<0.001$ \\
\hline $\begin{array}{r}\text { 4.1. School } \\
\text { enrolment }\end{array}$ & '0.17 [-0.04-0.40], 0.117 & $-0.23[-0.36--0.1],<0.001$ & $0.31[0.17-0.45],<0.001$ \\
\hline $\begin{array}{r}10 . \text { No health } \\
\text { restrictions related to } \\
\text { disability }\end{array}$ & $0.65[0.42-0.88],<0.001$ & $-0.22[-0.37--0.08], 0.003$ & $-0.02[-.18-0.13], 0.776$ \\
\hline
\end{tabular}

Probit models accounting for correlation between error terms. Adjusted for age, gender, household head disability status, distance to the nearest health facility and district 